\title{
Board Size, Non-Executive Board Members and Financial Performance in Non-Usury Banks in Iran
}

\author{
GholamReza Karami', Tahere Karimiyan², MohammadSadegh Ghaznavi ${ }^{3}$
}

\begin{abstract}
Prior studies investigating the relation between the financial performance and corporate governance mechanisms for firms in Tehran Stock Exchange mainly exclude banks due to their different types of rules and structure. We study the relation between corporate governance structure and financial performance of the banks under the non-usury banking act. We study various corporate governance factors including board size and the number of non-executive board members using a sample of 21 banks for 2010 to 2012. Result show a significant positive correlation among board size and financial performance. However, non-executive board members do not correlate with financial performance.
\end{abstract}

Keywords: Board size, financial performance, non-executive board members, non-usury banking.

Available Online: 01-07-2016.

This is an open access article under Creative Commons Attribution 4.0 License, 2016.

\subsection{INTRODUCTION}

In the aftermath of the great revolution in the infrastructure of economic agencies, the concept of control has changed. These changes led to the emergence of new topics such as the agent-owner relationship in economic agencies. With the growth of scope of stakeholders as owners, it is necessary for economic institutions to adopt a new approach to business to protect the interests of all stakeholders; hence, agency relationships must be based on morality and justice. Corporate governance is regarded as a mechanism for numerous agency issues. Governance concepts have an important role in aligning the interests of the owner and agent, and ultimately the successful control which is measurable through performance. Since 1983, the non-usury banking laws are governing the activities of banks in Iran. This law considers the purpose of the establishment of banking system as to establish the monetary and credit systems based on justice and truth (of Islamic principles) to regulate the appropriate flow of money and credit required for a healthy economic growth (Non-usury Banking Act, Article 1).

Because depositors cannot vote in the board, in the event of failure to secure truth and justice for the realization of their interests, this group is only able to withdraw its funds from the banks. However, the

\footnotetext{
${ }^{1}$ Associate Professor of Accounting, Faculty of Management, University of Tehran, Iran. Email: ghkarami@ut.ac.ir

${ }^{2}$ Faculty of Management, University of Tehran, Iran. Email: tahere.karimian@yahoo.com

3 Faculty of Management, University of Tehran, Iran. Email: sadegh.ghaznavi@gmail.com
} 
bulk of financial resources of banks are the depositors' funds. According to agency theory, the withdrawal of these funds represents the agency costs and thus will have a negative impact on the performance of banks. Especially in developing countries, banks are the main part of each economy (Morekwa \& Temesgen, 2013); and their dysfunction poses a systematic risk to the entire economy and also affects the performance of other sectors of the economy. In addition to the interests of shareholders, corporate governance also maintains the confidence of depositors in banks by reducing information asymmetry.

Many studies about the relationship between corporate financial performance and corporate governance mechanisms can be found in the literature of researches, in all of which, banks are excluded because of different rules and structure (Mashaiekhi \& Bazzaz, 2008). Also, studies about the impact of corporate governance mechanisms on the performance of banks in other countries show various results (Wasiuzzaman \& Gunasegavan, 2013; Morekwa \& Temesgen, 2013, 248; Al-Shammari \& Al-Saidi, 2013). On the other hand, investigating the relationship between corporate governance and financial performance of banks enables these institutions to make better decisions related to the board and relevant committees. Therefore, in this study the relationship between corporate governance and financial performance of banks under non-usury banking laws are examined.

In this regard, in order to increase the accuracy of results, appropriate control variables in three levels including macro-level of economy, industry-level, and bank-level is taken into account. Then, corporate governance in the banking system and the agency theory peculiar to the Islamic financial system (nonusury banking) has been proposed and after a review of the studies on the Islamic corporate governance, the results are presented in the course of descriptive and regression analyses of data. At the end, the research findings, suggestions and limitations are provided.

\subsection{REVIEW OF LITERATURE}

\subsection{CORPORATE GOVERNANCE IN THE BANKING SYSTEM AND ITS UNDERPINNING} THEORIES

The Organization for Economic Cooperation and Development (OECD) defines corporate governance as the set of relations between shareholders, the board of directors, and all stakeholders of an organization. Controlling the conflict of interests arising from the relationships between stakeholders inside and outside the firm is one of the arguments which became very important after integration of capital markets and event of globalization (Al-Shammari \& Al-Saidi, 2013). In this regard, corporate governance mechanisms are very effective and important elements in banking issues.

Theoretically, good corporate governance in both financial and non-financial institutions and agencies increase their performance. Empirical studies also have shown that investors tend to pay on average 10 to 12 percent for companies with strong corporate governance (Khanchel, 2007). In addition, paying attention to corporate governance in banks is of the highest importance compared to non-financial enterprises for the following reasons:

- Due to the diversity of stakeholders in banks, the agency relationship is complex and agency costs are high, so specific governance should be formulated.

- Banks are one of the main engines of economic growth in the economy of developing countries in which economy is often dependent on their monetary and banking system (Mullineux, 2006).

- Banks inherent risk is high due to the specific type of capital structure and through the use of financial leverage. These leverages often create short-term claims against the bank, while the banks use these funds for long-term plans (Morekwa \& Temesgen, 2013, 248).

- In most countries, including the developed and developing ones, receive and payment process is done through the banking system; on the other hand, banks are recognized as one of the major shareholders in many of these companies and other companies and have the right to vote in the 
meetings; so, banks have an important role in corporate governance of other non-financial companies (Mullineux, 2006).

To explain the application of agency theory for corporate governance, Fama and Jensen (1983) state that agency theory provides adequate monitoring mechanisms to reduce conflict of interests between management and shareholders and between shareholders and holders of debt securities (Al-Shammari \& Al-Saidi, 2013).

Agency relationships in Islamic banks (under non-usury banking law) are different from conventional banks. The main reason for this difference is the wide range of stakeholders and their different evaluation criteria. The most important stakeholders in the non-usury banking system include the board, shareholders and depositors.

In conventional agency relationship, the conflict of interests is mainly between management and shareholders, but in the banks under non-usury banking law, in addition to this type of relationship, the conflict of interest between shareholders and depositors and between depositors and borrowers make corporate governance of high importance.

In fact, agency relationship exists on both sides of the balance sheet of these banks. In the banking system, the role of board as a mechanism of corporate governance is crucial for the banks. Hence, the board is a key element to monitor the director's behavior to ensure that his/her decisions are made in accordance with the demands of the shareholders (Morekwa \& Temesgen, 2013, 248). If the Board of directors evades monitoring with respect to the interests of shareholders, shareholders can dismiss them with their right to vote. In conventional banks, fixed payment to depositors prevents the intensified conflict between the interests of depositors and shareholders. Payment of a fixed interest is forbidden under Islamic law and depositors have to go through modaraba partnership and agreements and participate in PLS return and risk shared by the banks. The unrestricted investment account holders (UIAH) or the long-term depositors cannot vote in board decisions, while their funds are separately or in combination with various stakeholders' funds invested on various plans. Management can hide the actual returns of depositors in favor of its own or the shareholders' interests, through misguided reporting of financial statements. So depositors can withdraw their funds from the bank to protect their interests. Withdrawal of the resources reduces profitability and has a negative impact on performance. Another reason that leads to the departure of both shareholders and depositors is the failure of observing obedience of Islamic laws in trading and investment projects by banks. With regard to the possible withdrawal of resources from banks, Islamic banks attempted to create various regulatory bodies at the macro level and also at the level of each bank. Among these institutions are the supervisory bodies on Islamic legal issues (Shariah). At each bank, a committee is formed called Sharia Supervisory Board that its decisions are binding and monitors the decisions made by the board of directors. This Board also considers and evaluates the products and services in compliance with the Sharia laws. The existence of Sharia Supervisory Board in the corporate governance of banks represents the theory of stakeholders in the governance (Magalhães \& Al-Saad, 2013).

In his article titled "Corporate Governance from an Islamic perspective: a comparative analysis based on the governance principles of OECD", Abu-Tapanjeh (2009) matched Islamic corporate governance with the four dimensions of the fundamental principles of OECD governance: transparency, fairness, accountability, and responsibility. But the distinction between the two was the important role of stakeholders in the Islamic governance in all aspects. Therefore, in this study stakeholder theory is considered in addition to agency theory.

\subsection{THE REVIEW OF EMPIRICAL STUDIES}

The larger board size has been faced with issues that may have an undesired effect on the company's performance. Issues such as lack of effective communication of members with each other, excessive bureaucracy, and the problem of coordination between members in making consensus decisions lead to 
costs which affect performance. According to agency theory, because of such costs, there should be limits on the number of board members. Experimental studies in the field of banking found various results regarding the effect of board size on performance:

Belkhir (2009) investigated the relationship between 174 banks during 1995-2002 and found that the larger board size had a positive effect on the performance of these banks. Rehman and Mangla (2013) examined a diverse sample of Pakistani banks including Islamic and non-Islamic, private and public banks and found that the board size has a positive correlation with performance and as the board grows bigger, better decisions are made and the profitability increases.

Wasiuzzaman and Gunasegavan (2013) compared Islamic and non-Islamic banks in Malaysia and found that the board size is not effective on profitability. Also, the board size is larger in conventional banks than Islamic banks. In conventional banks due to lack of committees such as Sharia Supervisory Board, the activities of the board shall not be monitored and the possibility of ignoring the interests of depositors and clients in favor of the interests of shareholders and management exists. Hence, the larger board and more members can be considered as a tool to control such issues. Regarding the study by Morekwa \& Temesgen, $(2013,248)$ in commercial banks in Kenya, the larger size of the board has a bad effect on the performance of the bank. This finding is consistent with agency theory. Because according to this theory, more members create more coordination problems and conflict of interests. Al-Shammari and Al-Saidi investigated nine Islamic banks in Kuwait and reported that the board size has an inverse relationship with performance. Hence, the smaller board size leads to less effective supervision and this way the performance of banks improve.

The executive board of directors includes full-time members of the firm who should take care of their everyday roles and responsibilities at the first place. So in addition to lack of independence and attachment to the executive chief officers and the chief director in doing their tasks related to the board, they face ambiguity in separation of duties. Non-executive board is less likely to comply with the demands of executives and against the interests of shareholders. Based on agency theory, Fama and Jensen (1983) expressed that the greater number of non-executive members on the board, leads banks to improve oversight and thus the conflict of interests between stakeholders is reduced. It also controls the opportunistic behavior of management in favor of stakeholders' interests (Al-Shammari \& Al-Saidi, 2013). Moreover, the existence of non-executive members in the board of directors suggests that executives are constantly under evaluation. Non-executive board members are influencing on the quality of decisions, strategies and performance improvements. Empirically different conclusions about the effect of non-executive board on the performance of the banks exist.

Wasiuzzaman and Gunasegavan (2013) compared the performance of 12 Islamic and 9 non-Islamic banks in Malaysia during 2005- 2009 and found that the independence of board members is greater in Islamic banks compared to non-Islamic ones. The reason of greater independence is due to the existence of Sharia Supervisory Board; because this board supervises the decisions and performance of board and prevents making a profit at any price. In this study, a poor correlation between the non-executive board members and the banks performance in both banks was reported. Al-Shammari \& Al-Saidi, (2013) conducted a study titled as "the board composition and bank performance in Kuwait" and studied nine banks as samples. They found that the ratio of non-executive members of board has no effect on performance; however, this is against agency theory which indicates all firms utilize from an independent board. They justified their finding as members' independence has not been formed well and the commercial knowledge of members was not enough. Morekwa \& Temesgen, $(2013,248)$ studied 37 commercial banks in Kenya during 2005 to 2009 found that, the larger size of the board improves the firm performance. According to the agency theory, the non-executive board members improve supervision on the conflict of interests and reduces agency costs; leading to better final performance.

Studies in the field of corporate governance and bank performance are fairly limited in Iran. Mashaiekhi and Bazzaz (2008) studied the information of non-financial companies listed in TSE in 2005 and 2006 and investigated the effect of corporate governance mechanisms on company's performance. They studied 
the effect of several variables including board size, board independence, and the presence of institutional investors on the return on assets, return on equity, and earnings per share and found that board size is inversely correlated with company performance. The results of this study show that the presence of independent directors strengthens the performance of the companies investigated; however no positive correlation was reported between institutional investors in the board and company's performance. Yeganeh, Raeesi, and Hosseini (2009) ranked companies in terms of corporate governance using questionnaires; and investigated its effect on the company's performance. However, they reported no significant relationship between the quality of corporate governance and the firm performance. Mo'tameni, Javadzadeh, and Tizfahm (2010) conducted a study titled as "banks' strategic performance evaluation" using Fuzzy Multi-Criteria Decision Making method to evaluate the performance of banks and finance and credit institutes. In this study, evaluation criteria was obtained using experts' idea and library sources in both financial and non-financial performance of banks and then the criteria were weighted using hierarchical analysis and were ranked using Topsis method. In evaluating financial performance, the criteria were ranked in terms of importance as: 1) the share of resources, 2) the profitability and 3) return on assets. The results indicate that non-financial performance is more important and having high financial performance is not a good support to expect a good overall performance of the bank. Therefore, in the present study the structure of the board that was regarded as one of the factors affecting financial and non-financial performance in previous studies and its effect on the financial performance of banks is investigated.

Given the review of experimental and theoretical studies, the following research hypotheses are tested. First hypothesis: a significant relationship exists between board size and financial performance in banks under non-usury banking law.

The second hypothesis: non-executive board members have a significant correlation with financial performance in banks under the non-usury banking law.

\subsection{DESIGN AND DATA COLLECTION PROCEDURES}

This research is an applied one and beside this, a descriptive approach is adopted to address the main research problem. Also, to describe the results and findings the correlation coefficient was used. The effect of corporate governance on the performance of Islamic banking in Tehran Stock Exchange is the domain of this study. Meanwhile, the information of three years was studied, from 2010 to 2012. This time period was selected because of the availability of the required information for this study. Thus, 21 nonusury banks were examined. To collect the data related to the governance and performance of banks, the financial statements on file with TSE and website of the surveyed banks were used. Iran's economic time-series information can be extracted from the Central Bank of the Islamic Republic of Iran and the World Bank database.

\subsection{RESEARCH VARIABLES}

The corporate governance standards change over time and depending on the geographical and cultural situations (Khanchel 2007). For this reason, the mechanisms of corporate governance which were common between different communities were extracted from studies by Khanchel (2007), Majid, Sulaiman \& Ariffin (2011), Darmadi (2013), and Al-bidehny (2013) and the constitution of the Islamic Republic of Iran's Central Bank, Tehran Stock Exchange's Corporate Governance Code and Corporate Governance Guide of Malaysia.

Banks like other firms have specific characteristics that can affect their performance. These factors include equity ratio, liquidity, loan loss provision ratio and more. Inflation is an important factor in the performance of banks. The effect of inflation on the bank's performance depends on anticipated or notanticipated inflation. If rise of inflation is fully anticipated and the received interest rate for the given loans and deposit accounts are adjusted, it will have a positive effect on performance. But if this forecast 
has not been made, and the banks slightly adjust their interest rates, then bank fees may be increased faster than revenues, which reduces the performance of the bank. In addition to macroeconomic factors, industry specific factors also affect the performance of banks. In developing countries due to lack of competition in the financial markets, demand for banking services is more (Floros \& Tan, 2012). Thus, a greater share of bank deposits to GDP than the share of capital market of companies listed in stock exchange to GDP represents smaller financial markets.

In his article, Bashir (2000) aims to examine the determinants of profitability and return margin ratio in Islamic banks, and states that as the financial markets act better, banks find more profitable opportunities. Because the development of stock markets and thus the availability of financing sources for companies make it possible to reduce the default risk of facilities received by these companies and they find a greater capacity to get loans from banks.

On the other hand, the development of capital markets improves transparency enabling the banks to better assess and monitor the credit risks of facility's applicant company. Hence, the risks of commercial banks reduce (Floros \& Tan, 2012). As a result of reduced business risk and development of capital markets, the performance of banks improve. The existence of such control variables can increase the accuracy and reliability of the results. Therefore, in this study, the control variables affecting the performance of banks are examined at bank, industry, and macroeconomic levels.

To test the research hypotheses the following model was used:

$R O A=\alpha_{0}+\beta_{1} B S+\beta_{2} C O M+\beta_{3} N E D+\beta_{4} C A+\beta_{5} L A+\beta_{6} B S D+\beta_{7} S M D+\beta_{8} I R+\beta_{9} L O A N L O S S+\varepsilon_{i}$

Table 1: Variables, operational definitions, and notations.

\begin{tabular}{|c|c|c|}
\hline Variable & Notation & Operational Definition \\
\hline \multirow[t]{2}{*}{ Return on Assets } & ROA & Net Income divided by average assets \\
\hline & BS & Number of board members \\
\hline Corporate Governance & NED & $\begin{array}{l}\text { Ratio of Non-executive to Executive board } \\
\text { members }\end{array}$ \\
\hline Equity Ratio & $C A$ & Ratio of Equity to Total Assets \\
\hline Liquidity Ratio & LA & Ratio of Cash to Total Deposits \\
\hline Share of Deposit from GDP & BSD & Ratio of assets from deposits to GDP \\
\hline Share of Financial Markets from GDP & SMD & Ratio of Market cap of listed companies to GDP \\
\hline Inflation & IR & Inflation Rate \\
\hline Credit Risk & Loan Loss & $\begin{array}{l}\text { Ratio of doubtful accounts allowance to Net } \\
\text { loans }\end{array}$ \\
\hline
\end{tabular}

\subsection{RESULT}

\subsection{DESCRIPTIVE ANALYSIS}

Table 2 presents the descriptive statistics for banks under the non-usury banking law in Iran. As the results of this table shows, the number of board members at Iran banks is 5 members which are consistent with the minimum determined by the Central Bank's statute. Also, the average return on assets is 1.92, which is bigger than the return reported for non-financial firms by Mashaiekhi and Bazzaz (2008).

In other words, banks have higher return on assets compared to non-financial companies. The average of non-executive board members shows that the boards of Iranian banks have fewer non-executive members on average, which is contrary to Article 57 of the statute issued by the Central Bank of Iran. 


\begin{tabular}{lrrrrrrrrr}
\hline \multicolumn{10}{c}{ Table 2: The descriptive statistics of banks under non-usury banking law } \\
\hline & ROA & BS & NED & CA & LOAN & LA & BSD & SMD & IR \\
\hline Mean & 1.92 & 5.76 & 0.56 & 11.97 & 4.71 & 16.23 & 78.89 & 45.85 & 15.41 \\
Median & 1.25 & 5.00 & 0.60 & 8.06 & 2.77 & 1.84 & 52.34 & 20.50 & 12.40 \\
Maximum & 8.40 & 9.00 & 1.00 & 63.54 & 65.72 & 571.92 & 146.93 & 165.80 & 30.50 \\
Minimum & 0.05 & 3.00 & 0.00 & 1.67 & 0.00 & 0.02 & 43.56 & 1.37 & 1.66 \\
St. Deviation & 1.73 & 1.47 & 0.32 & 11.53 & 9.46 & 65.72 & 46.41 & 57.00 & 11.05 \\
Total & 145.76 & 438.00 & 42.89 & 909.97 & 357.85 & 1233.72 & 5993.46 & 3484.53 & 1171.22 \\
Observations & 46 & 46 & 46 & 46 & 46 & 46 & 46 & 46 & 46 \\
\hline
\end{tabular}

\subsection{REGRESSION ANALYSIS}

This study aimed to investigate the effect of corporate governance on the performance of banks under non-usury banking governance mechanisms including the size of the board and non-executive board members for 21 private banks listed in the Tehran Stock Exchange during 2010 to 2012 using the regression equation mentioned above.

First of all, Chow test was run to prove the fixed effects. The results in table 3 show that at the significant level of 0.05 , the null hypothesis of equality of intercepts is not rejected and the proposed model is pooled. The estimated model is significant at the level of 0.01 and the coefficient of determination shows that the independent variables explain about 40 percent of the dependent variable. Durbin-Watson statistic indicates that there is no autocorrelation in the error term.

\begin{tabular}{lrrrr}
\hline \multicolumn{5}{c}{ Table 3: The results of the model's fitness } \\
\hline Variable & Coefficient & Standard Error & T statistics & P Value \\
\hline BS & 0.29 & 0.12 & 2.39 & 0.02 \\
NED & -0.12 & 0.68 & -0.18 & 0.86 \\
CA & 0.06 & 0.02 & 3.72 & 0.00 \\
LA & 0.00 & 0.00 & 0.09 & 0.93 \\
LoanLoss & 0.00 & 0.02 & -0.02 & 0.99 \\
BSD & -0.01 & 0.01 & -1.70 & 0.09 \\
SMD & 0.00 & 0.00 & -0.13 & 0.89 \\
IR & 0.02 & 0.02 & 0.71 & 0.48 \\
Constant & 0.36 & 1.12 & 0.32 & 0.75 \\
Coefficient of & & & Adjusted R & \\
determination & 0.4 & & & 0.33 \\
F-Statistics & & & Durbin-Watson & \\
Prob. F & 5.65 & 0.23 & Prob. \\
F statistics (Chow) & 0.00 & & & 2.12 \\
& & & & 0.79 \\
\hline
\end{tabular}

Board size is positively related to bank performance at significance level of 0.05 . This result is inconsistent with previous studies of Al-Shammari \& Al-Saidi, (2013), Morekwa and Temsegen (2013), and agency theory. Because according to this theory, more members create more coordination problems and conflict of interests. On the other hand, these findings are contradictory to Wasiuzzaman \& Gunasegavan, (2013), that indicate the board size is not effective on the profitability in Islamic and non-Islamic banks in Malaysia. The second part of their findings shows that board size of conventional banks in Malaysia is bigger than that of its Islamic banks. In conventional banks due to lack of supervising boards such as Sharia Supervisory Board the activities of the board of directors shall not be monitored and the possibility of ignoring the interests of depositors and clients in favor of the interests of shareholders or management exists, so more members enter to the board to control this problem. 
Hence, as observed in Iran's banks the positive relationship between board size and performance can be regarded as consistent with the results of the second part. In addition, observations from Iranian banks can be justified from the perspective of stakeholder theory. If the return on assets is considered as a measure of bank performance for all stakeholders, particularly depositors; the positive relationship between board size and performance can be regarded as an effective mechanism for achieving the goal of stakeholder theory i.e. accountability for a wider range of stakeholders (in addition to the shareholders). Thus the first hypothesis cannot be rejected.

Similar to the study in Kuwait by Al-Shammari \& Al-Saidi, (2013), no significant relationship was found between the ratio of non-executive board members and the performance of banks in Iran. Thus, the second hypothesis is rejected. It might be concluded that due to absence of Sharia Supervisory Board in the banks, no relationship exists among the number of non-executive directors and performance of Iranian banks. In addition, board composition may also not include an appropriate balance between the executive and non-executive directors.

Among the control variables studied in Iranian banks, equity ratio and the ratio of bank deposits to GDP are correlated with performance. The equity ratio's positive correlation was also reported by Bashir (2003), Choong et al (2012), Wasiuzzaman \& Gunasegavan, (2013). In fact, this positive correlation is a kind of assurance on the bank security and builds trust for clients regarding banks' performance. This means that the minimum capital to deal with problems arising from unforeseen losses and ensuing high flexibility is provided by the shareholders.

\subsection{CONCLUSION}

This study examined the relationship between corporate governance and performance of banks. Accordingly, observations on the performance and some mechanisms of corporate governance in banks under non-usury banking Law were studied for the period 2010 to 2012. The results from first hypothesis indicate that there is a relationship between the number of board members and financial performance. The results in relation to the second hypothesis showed no significant relationship between the role of non-executive members and the financial performance.

\subsection{RESEARCH LIMITATIONS}

Regarding that the privatization of Iranian banks and availability of data and information has been a recent issue; hence the existing corporate governance data are not complete. Further information about the studied companies can be adopted in future studies so that more reliable results are obtained.

\subsection{SUGGESTIONS FOR FUTURE RESEARCH}

1. Checking the different mechanisms of corporate governance in banks of Iran will be effective in regulating the circulars issued by the central bank. One of these circulars is the directive of the central bank for non-government-owned commercial banks. In this circular the structure of the ownership and board structure are the main issues. Therefore, according to the findings of the research on corporate governance, it is suggested that the central bank considers these results in setting the example statute for non-government-owned commercial banks and uses these findings to strengthen corporate governance in the Iranian banks. For example, given the positive relationship between board size and performance in this study, a maximum of twelve board members listed in the statute of the central bank can be revised to avoid a waste of resources, if necessary.

2. In one of the research findings, a significant correlation was found among a component of corporate governance and performance. However, corporate governance can be considered as a concept with diverse components which make a better judgment on the issue of governance if the attention is paid to all of them. But there is no ranking in Iran which is based on the composition of diverse components of 
corporate governance. Hence, it is suggested that the institutions which are responsible for developing and publishing rankings, take the diverse components into account. Because access to rankings based on the diverse factors enables us to judge the effect of corporate governance on the banks' performance with more certainty.

\subsection{SUGGESTIONS FOR FUTURE RESEARCH}

1. In this study the relationship between corporate governance and financial performance of banks were quantitatively investigated. Another method to address this issue is through qualitative approach. It is suggested that in future studies the effect of corporate governance on the financial performance of Iranian banks is investigated through survey and interview with banking experts, to provide a qualitative model.

2. Also, regarding that corporate governance studies are at the category of strategic and management studies, and the effects of governance structure reveal in the long-run; it is suggested that the relationship between corporate governance and other features (such as accounting-based efficiency ratios) of the banks which are under non-usury banking law are investigated in longer terms.

\section{REFERENCES}

Abu-Tapanjeh, A. M. (2009). Corporate governance from the Islamic perspective: A comparative analysis with OECD principles. Critical Perspectives on Accounting 20, 556-567.

Al-Baidhani, A. M. (2013, May 22). The Effects of Corporate Governance on Bank Performance. Retrieved from http://ssrn.com: 2284814

Aljifri, K., \& Khandelwal, S. (2013). Financial contracts conventional and Islamic financial institutions: an agency theory perspective. REVIEW OF BUSINESS AND FINANCE STUDIES, Vol.4 No.2, 79-88.

Alnasser, S. A., \& Muhammed, J. (2012). Introduction to corporate governance from Islamic perspective. Humanomics, Vol. 28 No. 3, 220-231.

AL-Saidi, M., \& AL-Shammari, B. (2013). Board composition and bank performance in Kuwait: an empirical study. Managerial Auditing Journal, Vol. 28 No.6, $472-494$.

Bashir, A.-H. M. (2000). Determinants of Profitability and Rate of Return Margins in Islamic Banks: Some Evidence from the Middle East. prepared for the ERP`s Seventh Annual Conference to be , (pp. 1-28). Jordan.

Bashir, A.-H. M. (2003). Determinants of Profitability in Islamic Banks: Some Evidence from the Middle East. Islamic Economic Studies Vol. 11, No. 1, 31-57.

Belkhir, M. (2009). Board of directors' size and performance in the banking industry. International Journal of Managerial Finance Vol. 5 No. 2, pp. 201-221.

Choong, Y. V., Thim, C., \& Kyzy, B. T. (2012). Performance of Islamic Commercial Banks in Malaysia: An Empirical Study. Journal of Islamic Economics, Banking and Finance, Vol. 868 No. 2, 67-80.

Darmadi, S. (2013). Corporate governance disclosure in the annual report An exploratory study on Indonesian Islamic banks. Humanomics Vol. 29 No. 1, 4-23.

Department of Studies and Regulations of the Central Bank of Iran (2013). Constitution of NonGovernmental Commercial Banks.

Donaldson, L., \& Davis, J. (1991). Stewardship Theory or Agency Theory: CEO Governance and Shareholder Rturns. Australian Journal of Management, Vol.16 No.1, 49-65.

HasasYeganeh, Y. (2005). Theoretical Foundation of corporate governance. Journal of Accountant, 20(1): 10-13.

Hassas Yeganeh, Y., Raeesi, Z., and Hoseini, M. (2009). Relationship between Quality of Corporate Governance and Corporate Performance in Tehran Stock Exchange. Journal of Iranian Management Sciences, 13(4): 75-100.

Khanchel, I. (2007). Corporate governance: measurement and determinant analysis. Managerial Auditing Journal Vol. 22 No. 8, 740-760. 
Magalha es, R., \& Al-Saad, S. (2013). Corporate governance in Islamic financial institutions: the issues surrounding unrestricted investment account holders. CORPORATE GOVERNANCE, 39-57.

Majid, N. A., Sulaiman, M., \& Ariffin, N. (2011). Developing a Corporate Governance Disclosure Index for Islamic Financial Institutions. 8th International Conference on Islamic Economics and Finance (pp. 125). Doha: Center for Islamic Economics and Finance, Qatar Faculty of Islamic Studies, Qatar Foundation.

Mashayekhi, B., \& Bazaz, M. (2008). Corporate Governance and Firm Performance in Iran. Journal of Contemporary Accounting \& Economics Vol4, No 2, 156-1 72.

Morekwa, E., \& Temesgen, K. (2013). The effect of governance on performance of commercial banks in Kenya: a panel study. CORPORATE GOVERNANCE, Vol.13 No.3, 236-248.

Motameni, A., JavadZadeh, M., and TizFahm, M. (2010). Evaluation of banks' governance performance. Journal of Strategic Management Studies, 1: 141-159.

Mullineux, A. (2006). The corporate governance of banks. Journal of Financial Regulation and Compliance Vol. 14 No. 4, pp. 375-382.

Olson, D., \& Zoubi, T. (2008). Using accounting ratios to distinguish between Islamic and conventional banks in the GCC region. The International Journal of Accounting 43, 45-65.

Quttainah, M. A., Song, L., \& Wu, Q. (2013). Do Islamic Banks Employ Less Earnings Management? Journal of International Financial Management \& Accounting 24:3, 203-233.

Rehman, R. u., \& Mangla, I. (2012). Does Corporate Governance Influence Banking Performance? Journal of Leadership, Accountability and Ethics vol. 9 No.3, 86-92.

Rosly, S. A., \& Abu Bakar, M. A. (2003). Performance of Islamic and mainstream banks in Malaysia. International Journal of Social Economics Vol. 30 No. 12, 1249-1265.

Tan, Y., \& Floros, C. (2012). Bank profitability and inflation the: case of China. Journal of Economic Studies, Vol.39 No.6, 39, 675-696.

Tehran Stock Exchange (2013). Statue of Corporate Governance.

Utama, C. A., \& Musa, H. (2011). The Causality between Corporate Governance Practice and Bank Performance: Empirical Evidence from Indonesia. Gadjah Mada International Journal of Business Vol. 13, No. 3, 227 - 247.

Wasiuzzaman, S., \& Gunasegavan, U. (2013). Comparative study of the performance of Islamic and conventional banks The case of Malaysia. Humanomics Vol. 29 No. 1, 43-60. 